between a succession from south-west England in which, during the Variscan orogeny, Upper Devonian shallow water sediments were followed first by deepwater shales, cherts and limestones and then by Namurian flysch, and certain Alpine successions in which shallow-water platform deposits were covered first by shales and fine-grained limestones with a purely pelagie microfauna and then by flysch. In both regions the arrival of flysch was heralded by a phase when sedimentation did not keep pace with downwarping. In contrast, Gill attributed the lack of flysch over the greater part of the Himalayas to the building up of land masses in Middle and Upper Eocene time.

Prof. A. Wood ${ }^{10-12}$ described some of the variations in lithology shown by the Aberystwyth grits which he employed to demonstrate the changes which could occur in turbidites as they are followed down-current. $\mathrm{He}$ discussed the behaviour of the associated mudstone and suggested that under certain conditions muds were stripped off and added to the turbid suspension passing overhead. Detailed work of this nature and of the kind carried out by Radomski in the Alps is beginning to establish the relationship between changes in facies and the several environments which might be expected in a single basin and seems likely to improve our understanding of the mechanism of turbidity currents.

Later in the discussion Mr. W. A. Cummins suggested that the finer-grained chloritic fraction of some greywackes might in part be a secondary feature. The apparent lack of contemporary greywackes might be explained in this way. Dr. J. G. Ramsay and Dr. J. L. Knill mentioned the difficulties which may arise in establishing the original attitudes of deformed sedimentary structures. Although, as Prof. Wood pointed out, account is usually taken of the effects of plunging structures, so far as I am aware the effects of shear folding in which the angle between a sedimentary structure and the fold axis alters during folding have not been considered. The results presented by Ramsay ${ }^{16}$ on this question should allow observations to be made in rocks deformed in this way.

Prof. Shackleton summarized present knowledge of Dalradian current directions ${ }^{18-15}$, and commented on the distribution of the various Dalradian sediments, some of which remain remarkably consistent from western Ireland to north-east Scotland. Dr. B. Sturt described variations within the Dalradian of Perthshire and Prof. Shackleton mentioned the recent recognition of turbidites near the base of the Torridonian succession in Colonsay and Islay.

One of the most arresting features of the symposium was the sequence of maps presented by Prof. M. Ksiazkiewicz ${ }^{3-9}$, which illustrated the results of measurements of current directions and facies analyses in the Polish part of the Carpathian flysch zone. This work, carried out by Prof. Ksiazkiewicz and S. Dzulynski, A. Slaczka, K. Zytko, W. Sikora, L. Koszarski and A. Radomski, has resulted in an elegant demonstration of the forms of the troughs and of the whereabouts and nature of the source areas. The varying directions taken by sediments were shown, and it was demonstrated, for example, that for a considerable time the axes of two neighbouring troughs sloped in opposite directions so that a northern trough was fed from the west and a southern from the east. These important results provide one of the most detailed accounts yet estab. lished of the movement of sediment within an evolving orogenic belt. I suggested, when summing up the day's discussion at the close of the meeting, that a synoptic account of comparable observations made in the British Palæozoic might be useful in bringing out what is known on this topic and what we need to find out in the future.

\section{J. SUTTON}

\section{Alps}

1 Tercier, J., Ecolog. Geol. Helv., 40, 164 (1947).

2 Trümpy, R., Bull. Geol. Soc. A mer., 71, 843 (1960). Carpathians

' Ksiazkiewicz, M., Ann. Soc. Geol. Pologne., 22, 399 (1952).

- Ksiazkiewicz, M., Geol. Rundschau., 45, 369 (1956).

s Ksiazkiewicz, M., Geol, Rundschau., 47, 418 (1958).

- Dzulynski, S., and Radomski, A., Anr. Soc. Geol. Pologne., 26, 225 (1956).

'Dzulynski, S., and Slaczka, A., Ann. Soc. Geol. Pologne., 205 (1958).

- Dzulynski, S., Ksiazkiewicz, M., and Kuenen, Ph. H., Bull. Soc. Geol. Amer., 70 (1959).

- Radomski, A., Acta Geolo Polonica, 8, 1089 (1958).

Wales

$1^{\circ}$ Rich, J. L., Bull. Amer. Assoc. Pet. Geol., 34, 717 (1950).

${ }^{11}$ Kuenen, Ph. H., Verh. Kon. Nederl. Akad. Wetensch., No. 20 (1953). 12 Wood, A., and Smith, A. J., Quart. J. Geol. Soc., 114, 163 (1959). Dalradian

${ }_{13}$ Knill, J. L., Proc. Geol. Assoc., 70, 273 (1959).

${ }_{14}$ Knill, J. L., J. Sed. Petrol., 29, 317 (1959).

${ }^{15}$ Sutton, J., and Watson, J., Proc. Geol. Assoc., 66, 101 (1955).

16 Ramsay, J. G., J. Geol., 69, 84 (1961).

\title{
ROCK ENGRAVINGS IN NORTHERN ITALY
}

COME years before the First World War, l'Institut A de Paléontologie Humaine was founded by Albert I, Prince of Monaco. Its various publications, not least the series of Archives, are of importance to every prehistorian. Memoire 31, entitled Le Grande Roche de Naquane, has maintained the standard. Rock engravings in the Val Camonica have long been known, especially as the result of the publications of G. Marro and R. Battaglia, but the time was ripe for this detailed study by M. Anati to appear. The carvings are found on rocks, many hundreds of them, up the valley for about 30 miles from near Boario to Edolo. A line drawn on a map from Bergamo to Bolzano will pass not far from the art complex. The author has attempted to separate these stylized drawings into three series: the first dating may be as old as the late Bronze Age, a second belonging to the Iron Age, and a third, which was still being made when Rome conquered northern Italy. A glance at the illustrations - there are no less than 52 full pagesreveals that there are depicted in a pocking technique animals, mainly domestic but including stags, human boings and various weapons and signs. The author decided not to select his illustrations from various sites in the complex, but to concentrate on a single rock surface. There is thus given a complete account of at least one locality from among the 600 or so which have been identified.

The Val Camonica is a long valley running up into the Alps, and it is probable that it has always been 
a highway for people passing north and south. But why for 30 miles or so folk should have taken the trouble to cover rocks with stylized figures of animals, men and signs remains a mystery. It is easy to talk about ritual, but that does not answer the question. Why the ritual, and what was it ? Similar rock art complexes are known, the most famous being those surrounding Monte Bego in the Ligurian Alps. While there is a certain similarity with those of the Val Camonica, there are also notable differences (the characteristic halberds of Monte Bego seem to be replaced by spears at Val Camonica and I do not remember any stags at Monte Bego), and in any event their connexion would rather be with the earlier series at the Val Camonica than with the later. At Monte Bego there is a thunderstorm almost daily at 3 p.m., due to the fact that it is the first high mountain inland from the hot Riviera coast. Local peasants, when asked what the weather will be, still say, "Let me see what the devil at Monte Bego is doing". One can imagine a reason for a ritual to take place from time to time at that mountain, but at Val Camonica such a reason would seem to be absent.

M. Anati is to be congratulated on producing a very useful and much-wanted work. Two criticismas must be added. No general index is supplied, and while there are references to a fow works in the text, there is no bibliography. This is a real nuisance. French publications seldom carry any index : a policy to be questioned. In the present case, its absence is a great inconvenience. But these two defects must not be allowed to detract from the real value of M. Anati's excellent work. MuLes BuRKITT

\section{HYPOTHERMIA AND THE EFFECTS OF COLD}

\begin{abstract}
$\mathrm{T}$ THE modern investigation of hypothermia in man can be said to date from the work of Temple Fay and G. W. Smith, carried out during 1938-39. They cooled patients suffering from inoperable carcinoma, in the hope that the lowered temperature would affect the new growth more than the rest of the body. The clinical work was complemented by physiological work by D. B. Dill and W. H. Forbes on hypothermic patients.

During the Second World War hypothermia became important as a factor in survival at sea. Shipwreck survivors rescued after prolonged immersion frequently died because of lowered body temperature. Much work on the effects of body-cooling was thus stimulated, with emphesis on the treatment of hypothermia rather than on its clinical use. After the War, A. H. Hegnauer and his associates at Boston started a systematic investigation of the physiology of hypothermia in the dog, and about the same time W. G. Bigelow began his work at Toronto with the possibility of using hypothermia as a surgical tool.

Since 1950, the subject has advanced very rapidly, particularly as the surgical advantages of hypothermia have become apparent. Smith and Fay reduced body-temperature to between $30^{\circ} \mathrm{C}$. and $32^{\circ} \mathrm{C}$., and this was a hazardous procedure. For a long time it was found to be dangerous to lower
\end{abstract}

\section{OPEN FORESTS IN TROPICAL AFRICA}

the temperature to below $27^{\circ}$ C. Now C. E. Drew and his colleagues cool their patients to below $15^{\circ} \mathrm{C}$.

A recent issue of the British Medical Bulletin contains a fascinating collection of articles describing present investigations and how the techniques of hypothermia are being used in medicine and surgery (17, No. 1 ; January 1961 : Hypothermia and the Effects of Cold. Pp. 1-78+xvii. London: British Council, 1961. 20s.). The articles include one by R. W. Salt on the resistance of poikilothermic animals to cold; hibernation in mammals by Dr. L. Harrison Matthews; local cooling in man by Dr. R. H. Fox; physiological effects of continued cold on animals and man by J. S. Hart; biochemicel changes in exposure and acclimatization to cold environments by Dr. F. Depoces; the technique of induced hypothermia by Drs. I. K. R. McMillan and E. S. Machell; profound hypothermia in cardiac surgery by Dr. C. E. Drew. Other articles include accounts of experimental deep hypothermia and the circulation in hypothermia; metabolism in hypothermia; hormones in hypothermia; the central nervous system in hypothermia and the effect of temperature on the response to drugs; and sensitivity of hypothormic mammals to X-irradiation. Prof. A. S. Parkes has acted as co-ordinator of the whole series.

\footnotetext{
DUBliCATION No. 52, issued by the Scientific Council for Africa South of the Sahara, contains selected papers presented at a conference of British, French, Belgian and Portuguese specialists held at Ndola, Northern Rhodesia, during November 17-23, 1959 , and also the recommendations made and the conclusions reached*.

The conference considered the forestry problem of what is generally referred to as miombo woodland which, from Katanga (Congo) to Southern Rhodesia,

* Scientifle Council for Africa South of the Sahara. CSA/CCTA Publication No. 52. Pp. 126. (London: Bureau of Publications, CCTA/CSA Secretariat, Watergare House, York Bulldings, W. 0.2 1960.)
}

covers some 670,000 square miles. The term miombo embraces several forest types ranging from dry high forest to savannah-woodland, but Brachystegia species are fairly typical of the treo canopy.

The sylviculture and management of the miombo woodland are made difficult by the large areas, the damage caused by fires, the low proportion of valuable species, the slow rate of growth, the long haulage distances, the limited uses of timbers which are not easy to work, slow to season, not durable and sometimes not possible to impregnate. Pterocarpus angolensis and the so-called Rhodesian teak, Baikiaea plurijuga, provide timber for constructional 